\title{
Refugee Camps on the Thailand-Myanmar Border: Potential Places for Expanding Connections among Karen Baptists
}

\author{
Boonsong Thansrithong and Kwanchewan Buadaeng*
}

Faculty of Social Sciences, Chiang Mai University, Chiang Mai 50200, Thailand

*Corresponding author. E-mail: kwanchewan.buadaeng@gmail.com

https://doi.org/10.12982/CMUJASR.2017.0006

\begin{abstract}
Since the 1980s, the Burmese army has increasingly seized the Karen National Union (KNU)'s camps and strongholds along the Thailand-Myanmar borderland. Hundreds of thousands of Karen people affected by the war have fled to the Thai side of the border. Since then, ten refugee camps have existed along the border, from Mae Hong Son province in the North to Ratchaburi province in the South. This paper focuses on the operation of the Kawthoolei Karen Baptist Bible School and College (KKBBSC) in the Bae Klaw camp, which is the largest with almost 40,000 residents in 2016. Since 1990, the KKBBSC has produced around 1,000 Bachelor of Theology graduates, thereby increasing the strength of the Karen Baptist church. This paper argues that the refugee camps on the Thailand-Myanmar border are not marginally isolated, but are potential nodes of connection with other places and organizations. Two factors contribute to the potentialities of the camps. First, the camp is an exceptional zone, ruled not by a single government but a liminal contested space of many actors. The second is the camp's high level of technological development which facilitates transportation and communication for the Karen Baptists. Thus, with the active role of Kawthoolei Karen Baptist leaders and close connection with and support from Karen and non-Karen Baptist and non-Baptist international organizations, the KKBBSC has increased its strength, leading to the expansion of Karen Baptist churches elsewhere in the world.
\end{abstract}

Keywords: Refugee camp, Thailand-Myanmar border, Karen Baptists, Exceptional zone 


\section{INTRODUCTION}

'Karen' is a generic term referring to an ethnic minority living around the eastern part of Myanmar and the western part of Thailand. The estimated population of the Karen in Myanmar is seven million while in Thailand it is half a million. ${ }^{1}$ Some of the Karen people of Myanmar live in urban areas such as Yangon and the Irrawaddy delta; others live in mountainous areas as well as along the Bay of Bengal and the Andaman Sea. The first baptism of a Karen in Myanmar was performed in 1826 by an American Baptist missionary, and the number of Karen Christians has increased since then. With support from both the colonial government and missionaries, the Karen attained higher education and enjoyed relatively high status as professionals, such as government officials and politicians. Karen national identity has been created based on constructed history, cultural performances, and a written language. ${ }^{2}$ The belief in the Karen as a nation is well illustrated in the statement below issued by the Karen National Union (KNU), a political organization representing the Karen people.

The Karens are much more than a national minority. We are a nation with a population of around 8-10 million, having all essential qualities of a nation. We have our own history, our own language, our own culture, our own land of settlement and our own economic system of life. By nature the Karens are [a] simple, [quiet], unassuming and peace [-loving] people, who uphold the high moral qualities of honesty, purity, brotherly love, co-operative living and loyalty, and are devout in their religious beliefs. (http://www.knuhq. org/about/the-karens-a-nation-their-nature-and-history/)

With the belief that a nation must rule itself, in 1948 when the British were in the process of granting Burma independence, the Karen launched a campaign for a separate autonomous state, but without success (Rajah, 1990; Renard, 1990; Gravers, 1996).

${ }^{1}$ Estimates of the Karen population in Myanmar are varied. Smith (1999:30) estimates that there are 3-4 million. The KNU website states the number at 8-10 million (http://www.knuhq. org/about/the-karens-a-nation-their-nature-and-history/). The Karen in Thailand mostly live in the hilly forest areas of many provinces. The figure is from the last survey in 2002 (Social Development and Welfare Department, 2002).

${ }^{2}$ The script called Liwa is invented, based on the Burmese script. 
Thus the Karen struggle for autonomous power has been in existence since the day of Burmese independence at the end of 1948. During the period 1962-1988, when Burma became a 'socialist' country and closed itself off from the outside world, the KNU and its armed force, the Karen National Liberation Army (KNLA), were about occupy the vast areas along the border with Thailand. The KNLA was increasing its strength as the KNU received sizeable income from taxing goods passing through its territory from Thailand to the inner cities of Burma, and also from logging and mining. However, in 1989 Burma, under the new name Myanmar, changed its political and economic policy and military strategy. ${ }^{3}$ The KNLA gradually lost its controlled territory and stronghold. Heavy fighting in the 1990s sent Karen people from the war zone in Myanmar to refugee camps in Thailand. Today ten refugee camps still exist along the border, from Mae Hong Son province in the North to Ratchaburi province in the South. The number of residents is still around 100,000 even after tens of thousands were relocated to third countries mainly before $2011 .^{4}$

In 1984, the KNU set up the Kawthoolei Karen Baptist Church $(\mathrm{KKBC})$ to oversee the evangelist and socio-economic development missions inside the KNU-controlled area. The KKBC also established the Kawthoolei Karen Baptist Bible School as an important means of producing missionaries and conducting evangelization and development among Karen people in the Kawthoolei area. The term Kawthoolei is literally translated with many meanings: 'green land', 'land without evil', 'land of thoo lei flowers' and 'land cool cave', in the Pwo Karen language. But in general, people understand it as a Karen country with its own autonomous power. It also carries the sense of an original homeland that the Karen must fight for and reclaim. As it is related to the KNU-led nationalist movement, it also means the territory governed by the KNU.

In 1990, when the fighting between the Burmese army and KNLA was escalating, the Kawthoolei Karen Baptist Bible School was also moved to Bae Klaw, the largest refugee camp. As it had set up a Bachelor in Theological Studies program, its name was changed to Kawthoolei Karen Baptist Bible School and College (KKBBSC). Since then, it has produced around 1,000 Bachelor of Theology graduates in the English and Karen programs. ${ }^{5}$ These graduates work in Myanmar and many other

\footnotetext{
${ }^{3}$ The 'Four Cuts' strategy was applied to cut the four main links that the KNU has with the Karen population, which are food supply, contact, finances and recruitment (see Keenan, 2011) ${ }^{4}$ Figure from http://theborderconsortium.org

${ }^{5}$ Estimated from the figure given by the late Rev. Dr. Saw Simon, the principal of the KKBBSC in an interview in 2012.
} 
foreign countries where the Karen people live, such as the USA, Australia, New Zealand, Canada, and Singapore with the majority in the USA. Horstmann (2011) elaborates that the Karen missionaries from the camp are actively converting Karen people in Thailand living around the camp. He concludes that refugee camps in the Thai borderland have become centers of proselytization, and that Protestant Christianity provides a crucial vehicle for political mobilization.

This paper endeavors to answer the question of why the Karen Baptists have been able to expand their connections in the borderland as well as worldwide despite being displaced in refugee camps. The authors agree with Horstmann's argument (2011) that the refugee camps have become centers of proselytization, but would emphasize that it is not only Christianity but also other religions which have prospered in the camps. The success of the proselytization, as this paper argues, does not depend only on the Baptist leaders but also, and more importantly, on the camp's potential as a liminal and exceptional zone. Here, two concepts - liminality (Turner, 1969) and state of exception (Agamben, 2005) - are used to explain the particular characteristics of the refugee camp. According to Agamben (2005), "the state of exception is not a dictatorship...but a space devoid of law, a zone of anomie in which all legal determinations - and above all the very distinction between public and private - are deactivated." Agamben also relates the state of exception to Victor Turner's concept of liminality, which is a situation that is "unnatural - or rather, anti-cultural or anti-structural" (2005). The two concepts will help to understand the refugee camp, which is a space devoid of Myanmar and Thai law, but with regulations resulting from the negotiations of many stakeholders. Refugees and displaced people are in a liminal, in-between position as they are denied Myanmar citizenship and not yet accepted as citizens of other countries.

In the sections that follow, after a description of the methodology used in the study, the paper will describe the research results which will be divided into three sections. The first section describes the refugee camps as an exceptional zone with well-connected transportation and communication technology. This enables the effective operation of the KKBBSC and Karen Baptist churches which are described in the following two sections. The discussion argues that the refugee camp at the border is not a marginally isolated place but an exceptional zone which helps to connect Karen Baptists elsewhere. However, as the refugee camp has existed for almost 40 years, the characteristics of its liminality as explained by Turner (1969) have also changed. 


\section{METHODOLOGY}

This paper is a partial result of Ph.D. research which applies the qualitative research approach. Two main methods were used to collect data during 2014-2015, in-depth interviews and participant observation. To understand the characteristics of the refugee camp as a potential for Karen Baptist connections, the interviews were carried out with Karen Baptist leaders who belong to the $\mathrm{KBC}^{6}$ in Myanmar, the $\mathrm{KKBC}$ in the refugee camps and the Thai Karen Baptist Church in Chiang Mai, the capital city of Northern Thailand. To understand the expansion of connections between Karen Baptists world-wide, in-depth interviews were also conducted with Karen Baptist leaders from foreign countries who have regularly organized Global Karen Baptist Fellowships (GKBF) in Chiang Mai, and often come to visit Karen refugees in the borderland. Participant observation has also been used to observe activities organized by the KKBC, KKBBSC, GKBF as well as by Baptist churches in foreign countries. As the first author is a Karen Baptist from the borderland and works for INGOs that have carried out humanitarian and development projects in the refugee camps, he was able approach the informants. The language for communication with the informants was Karen, Thai and English, whichever an informant preferred. As one among the Karen Baptists, he has not found any difficulty in participating in many events organized by them.

\section{RESULTS}

There are three important findings which answer the question of why the Karen Baptist Church, although in a displaced situation, has managed to expand its operation. First, the study's refugee camp where the KKBBSC is situated is an exceptional zone with flexible laws and regulations as negotiated by stakeholders: the KNU, the Thai state and international organizations. Second, the KKBC and the KKBBSC are efficient in producing young Karen Baptist missionaries, and third, the Karen Baptist churches of these leaders are mobile with regard to the national border. Further details of the three findings are as follows.

${ }^{6}$ The Karen Baptist Convention (KBC) has been in existence since 1913 for missions among the Karen in many states of Myanmar. It is a large organization with 20 church associations and 1,777 churches in 2014. 


\section{The refugee camp as a liminal and exceptional zone}

A refugee camp is a liminal zone following the definition of Turner (1969), with attributes "that ... are necessarily ambiguous.... Liminal entities are neither here nor there; they are betwixt and between the positions assigned and arrayed by law, custom, convention and ceremonial." The zone is exceptional because normal law is suspended or people's lives are no longer subject to juridical order while new order/norms are produced when necessary (Agamben, 2005).

Refugee camps on the Thai border do not fall under the sovereign power of a single state. Rather, at least three main stakeholders have played important roles in the camp management: the Thai state, the Karen National Union and the UNHCR and its related organizations. Law and order in the camps seems to be the result of negotiation among these parties and thus is not always stable. Each party has limitations on issuing its laws and thus, they have not been able to use normal law, as further described.

\section{The Thai state}

The Thai state has not signed the 1961 UN Convention on the Status of Refugees or the 1967 Protocol Relating to the Status of Refugees. ${ }^{7}$ Thus, those who fled from the war in Myanmar to Thailand are not officially called 'refugees', but rather 'illegal entrants.' In fact, however, the definition of refugee in Article 1 of the Convention below, applies to the Karen refugee, as one who

...owing to well-founded fear of being persecuted for reasons of race, religion, nationality, membership of a particular social group or political opinion, is outside the country of his nationality and is unable or, owing to such fear, is unwilling to avail himself of the protection of that country; or who, not having a nationality and being outside the country of his former habitual residence as a result of such events, is unable or, owing to such fear, is unwilling to return to it. ${ }^{8}$

\footnotetext{
${ }^{7} \mathrm{~A}$ total of 147 states are parties to the Convention and/or the Protocol as of 1 Sept 2007 (https://www.unhcr.or.th).

${ }^{8}$ https://www.ohchr.org/EN/ProfessionalInterest/Pages/StatusOfRefugees.aspx accessed on June 16, 2018.
} 
As the Thai state has not signed the convention, the term 'refugee camp' is not officially used, but rather, 'Temporary Shelter for Persons Displaced from Fighting.' However, for the sake of convenience and as it corresponds to the actual situation, this paper uses the term 'refugee' and 'refugee camp.' It is also noted that the Thai state does not recognize the Karen refugees but it has allowed the camps to be set up on a humanitarian basis. The Thai state also states that it upholds the non-refoulement principle and will not push the refugees back if they are prone to danger. ${ }^{9}$

Thus, the Thai state plays an important role in procuring the land on which refugee camps are located.$^{10}$ It is noticed that although the camp is called a 'temporary shelter', after 30 years, the refugees still remain in the camps and a plan for repatriation has yet to be made concrete. The Thai state's measures applying to the refugees have also changed. Before the 2000s, some young refugees went to find jobs outside the camps, even as far as the inner cities of Thailand. As the number of illegal migrants increased, the Thai state started a process of registering migrant workers from Myanmar and stopping illegal migration. Since then, the Thai state has also applied stricter measures to the refugees, starting with building barbed wire fences in 2004. The Ministry of Interior has also sent the most senior deputy district officer to a permanent base at the refugee camp to make sure that refugees do not violate Thai laws. These laws primarily involve the movement of refugees out of the camp. The camp gates are usually guarded by district office volunteers who prevent outside people from entering and refugees from leaving. NGOs are allowed to enter the camp to conduct project activities but they must notify the Thai officials beforehand. However, their staff are not alowed to stay overnight in the camp.

\section{The Karen National Union (KNU)}

Refugees who fled from the fighting between the Burmese Army and the KNU/KNLA can be classified into at least three groups. The first consists of KNU officials, including those working for KNU-related organizations, namely the Karen Women's Organization, Karen Youth Organization and the Kawthoolei Karen Baptist Church (KKBC). The second consists of KNLA soldiers and their families, including those handicapped from fighting. The third group are Karen villagers who

\footnotetext{
${ }^{9}$ The Thai official document is referenced in Masanthia (2000).

${ }^{10}$ Before the set-up of Bae Klaw camp, the land was rented out to the companies to grow trees for sale. The company sued the Thai government for damaging their business (Buadaeng, 2008).
} 
lived in the area controlled by the KNU and thus were affected by the fighting, but did not have an original village or their original villages are too far to return to. Therefore, moving to refugee camps is the only choice.

Karen refugees have been familiar with KNU law and order since the time they first began living in the KNU-controlled area. However, in the new situation of the refugee camps in Thailand, the KNU cannot continue fully administering law and order in the same way as before for the following reasons. First, they have to be careful not to violate Thai state sovereign principles and not to show that they have control over the people in the camp or the Myanmar state will complain and their relationship with the Thai state will be jeopardized. Second, as the camps have existed for many decades, camp members have become diversified as some of them who came later may not have been affected by the fighting but moved in the camp for business reasons. However, the KNU has still maintained some power or influence through people holding positions on the camp committee or working in related organizations. The following description of Bae Klaw camp demonstrates the vastness of its area, which accommodates diverse groups under the administration of the camp committee.

Bae Klaw camp is situated on the main road from Mae Sot district of Tak province to Mae Sariang district of Mae Hong Son province. It occupies an area of 1,150 rai (184 hectares), partly used to grow cotton and thus the Karen name Bae Klaw, literally meaning cotton field. The camp was established in 1995 by consolidating a number of smaller camps. It is larger than any of the nine other camps, with a population of 48,659 in 2006 . After some residents were relocated to third countries during 2005-2011, the population decreased to 26,186 in 2013. However, it increased again to 36,626 in 2018, as the fighting between the Burmese army and ethnic armed groups continue, sending people across the border to the refugee camps. The increase in population is also from babies born in the camp and from young people coming from the Karen state and elsewhere in Myanmar for education in the camp.

In Bae Klaw camp, there are 28 schools at the primary and high school level and five colleges operating at the higher education level. According to the Karen Refugee Committee Education Entity (KRCEE), the organization led by KNU members to support the operation of all schools in refugee camps, in 2017-2018 the number of students in Bae Klaw camp at the primary education level is 7,677 while in higher education it is 750 . The camp contains refugees from diverse ethnic 
groups with the Karen as the majority. Refugees also belong to many religions and denominations. There are five Buddhist temples, 15 Christian churches and six mosques.

Bae Klaw camp is administrated by a camp committee. The selection process starts from the selection of 10 representatives per section. As Bae Klaw camp has 15 sections altogether, 150 representatives meet. The camp committee organizes an ad hoc selection committee to operate the selection and count the votes. A person with a high level of education and who is a Baptist is usually selected. As in the camp, the KKBBSC teaches at a higher education level. Thus it is likely that a person who graduates from the KKBBSC will be elected to become a camp committee member and chair.

Thus although the camp seems to be a non-political space as KNU cannot fully exercise its administrative power, the influence of KNU can be found via individual camp and organization leaders. Chung-Chi (2012) also concludes that because of a tacit consensus between the Thai government's Ministry of Interior and the KNU, "refugee camps were transformed into 'Karen space' outside of Karen land, or Karen's 'non-territorial territory'."

\section{UNHCR and International Non-Governmental Organizations (INGOs)}

As the refugees are treated by the Thai state as illegal entrants, they are not allowed to leave the camp to work or conduct any activities outside the camp. ${ }^{11}$ Food and other basic needs are provided by the Border Consortium, which mobilizes monetary support from the UNHCR and many religious and non-religious organizations worldwide. Moreover, many INGOs including faith-based organizations also support the refugees in various sectors such as health care, education, and others. In 2015, there were 16 INGOs operating in the camp, namely the Burma Consortium (TBC), Première Urgence - Aide Médicale Internationale (PU-AMI), Shanti Volunteer Association (SVA), Adventist Development America Refugee Committee (ADRA), Right to Play (RTP), Solidarite, Catholic Office for Emergency Relief and Refugee (COERR), Shoklo Malaria Research Unit (SMRU), International Rescue Committee (IRC), Women's Education for Advancement and Empowerment (WEAVE),

\footnotetext{
${ }^{11}$ The Thai state does not have to comply with the convention, which guarantees many rights of refugees, such as the right to engage in wage-earning employment (Article 17) and self-employment including the establishment of commercial and industrial companies (Article 18).
} 
Handicap International (HI), Film Aid, Drug Abuse Resistance Education (DARE), Save the Child, PPAT and the Taipei Overseas Peace Service (TOPs).

As the UNHCR, TBC and other organizations take care of refugees in their living and well-being by means of a very substantial budget, they also have tried to insert their law and order in the management of the camp. The UNHCR registered the refugees in 2005, the year that the relocation program started. Only those with a UN card can apply for relocation. The UNHCR also collaborates with the Thai state on the repatriation program to make sure that it follows UN rules as specified in the Convention.

To summarize, the refugee camp has existed for more than thirty years because of the supportive operation of three main parties: Thai state, KNU and INGOs. The Thai state allows the establishment of the camp in its sovereign territory while the KNU has largely organized refugees in the camp and the INGOs provide food and other necessities for living. No party has absolute power to rule the camp, and thus cannot apply its normal law and regulations. Thus, the camp has specially set up its own rules as a result of the negotiation of the three parties. However, the camp's rules have not been stabilized as in the last three decades, the three parties have also changed their policies and strategies on matters related to ethnic war in the borderland. For example, after the coup d'etat in Thailand in 2014, the military-led government has applied more restrictive measures to prevent the refugees from venturing out of the camp. Also after 2013, food rations for refugees has been reduced due to funding cuts by international aid organizations, which diverts their funds to support development activities inside Myanmar.

\section{Operation of Kawthoolei Karen Baptist Church (KKBC) and} Kawthoolei Karen Baptist Bible School and College (KKBBSC) on the Thailand-Myanmar borderland

As described at the beginning of this paper, the Karen in Myanmar (then Burma) have been converting to Christianity since the early $19^{\text {th }}$ century through the efforts of American Baptist missionaries. During the colonial period, Karen socio-economic status was uplifted through education, which enabled them to become professionals in every sector of society. Karen national consciousness increased, leading to the establishment of the Karen National Association (KNA) in 1881. The Karen Baptist Convention (KBC) was established in 1913 and has since played 
a great role in evangelization and socio-economic development. ${ }^{12}$ The Christian-educated Karen leaders felt that the Karen should be considered a nation and thus not be under the Burmese. When Burma gained independence at the end of 1948, the Karen national movement under the leadership of KNU was launched and it continues even now.

During 1960-1970, the KNU was the only Karen political organization that controlled the Thailand-Myanmar borderland. The KBC churches in the KNU-controlled area, called Kawthoolei ${ }^{13}$ the Karen autonomous homeland - played a large role in producing educated Christians with nationalist ideas. However, with the Burmese army's Four Cut operation, ${ }^{14}$ the KBC churches in Kawthoolei were cut off from the KBC in Yangon and other parts of Myanmar. In 1983, the Karen Baptist leaders decided to set up their own organization called Kawthoolei Karen Baptist Church (KKBC), with their office located on the border across from Phobphra District of Tak Province of Thailand.

Since the 1990s, the KNU has lost important camps but was able to maintain seven brigades and local government. The KKBC has operated in these seven areas, ${ }^{15}$ each of which has its own church committee that oversees many Baptist churches. The KKBC has five working sectors; the evangelist department, women's organization, youth organization, education and Sunday school and the Kawthoolei Karen Baptist Bible School and College (KKBBSC).

The KKBBSC was set up at Htee Ka Haw village, Pa-an district, Karen state in 1983 as a small Bible school with four teachers and six students. But as the fighting escalated, it was moved to Bae Klaw refugee camp. Seven years after that, the school was in better condition and thus the school committees decided to open two new programs; the Bachelor of Theological Studies (BTS) and the Bachelor of Arts (Liberal Arts - BA), thus the name was changed to Kawthoolei Karen Baptist Bible School and College (KKBBSC). The BTS program is also divided into two types, the B.Th English program and the K.T.S. Karen program. In the 20132014 academic year there were 369 students, 189 male and 180 female, in the B.Th program, and 112 students, 60 male and 52 female, in the K.T.S. program. There were 30 teachers and officers working at the school while

\footnotetext{
${ }^{12}$ In 2014, the KBC had 20 church associations with 1,777 churches.

${ }^{13}$ Many literal meanings are given such as land without evil, green land etc.

${ }^{14}$ The Burmese Army's Four Cuts policy or strategy has been used since the 1970s to fight ethnic armies. It means the cutting off access to food, funds, information and recruitment. ${ }^{15} \mathrm{Hsar} \mathrm{Mu}$ Per, Koh LohTraw, Mae Ra Mu, Thumei, Taw Naw Mu Thaw, Blidawei and Hsaw Htit.
} 
another 10 teachers were pursuing higher degree studies in Nagaland (India), the Philippines and Canada. ${ }^{16}$ According to the late Reverend Dr. Saw Simon, the KKBBSC principal (interview, Apr. 26, 2012), since 1996, around 500 students had graduated from the B.Th English program and a few hundred from the K.T.S. program. After graduating, these students went to work as pastors, teachers and in other careers in Myanmar, USA, Australia, New Zealand, Canada and Singapore. The number of those who went to the USA both to study and to relocate is the highest.

Three interrelated factors are associated with the exceptional nature of the camp which enable the KKBBSC to become stronger and more efficient in its operation.

First, the refugee camp is perceived as a marginalized place with poor conditions where refugees are suffering, as they are displaced and living in hardship with no freedom of movement. For Christian believers, it is a place where faith in God is needed as only God can fulfill their hopes and lead them to salvation. Thus, the KKBBSC is seen as a necessary tool for the missions to assist Karen people in their dire situation. The KKBBSC draws a lot of sympathy and support from Karen and non-Karen Baptists, as well as other Christian denominations. Dr. Simon, the former KKBBSC principal, has earned a worldwide reputation for his dedicated work in the refugee camp. In 2000, he received a reward as a human rights defender from the Baptist World Alliance (Lee, 2001). In 2010, he became the first general secretary of the Global Karen Baptist Fellowship $(\mathrm{GKBF})^{17}$ and later one of its advisers. In 2012, he was formally recognized by the GKBF together with other outstanding Karen individuals for his hard work and dedication to the development of Karen people.

Second, although the refugee camp is fenced, residents can go out and outside people can enter. As observed by Lee (2001), refugees maintain networks outside the camp where they go back and forth to visit their families and relatives in Myanmar. If the refugees want to go out to other areas within the border provinces of Thailand, they can make a request to the camp committee, who will send the request form to the

\footnotetext{
${ }^{16}$ From Kawthoolei Karen Baptist Bible School \& College Calendar 2014. (https:/ / sites.google. $\mathrm{com} / \mathrm{site} / \mathrm{kkbbsc} /$ ).

${ }^{17}$ This is a group of Baptist Karen people living in many countries in Asia, America, Australia and Europe, who want to work together to help the Karen people who face difficulties, especially those living in refugee camps and IDP camps. It was first set up in 2007 atSiloam Bible School, Chiang Mai.
} 
Ministry of Interior. The camp also is located on a good road where public transportation is available, although strict measures regarding travel are applied from time to time. With convenient transportation and the semi-autonomous administration of the camp, the KKBBSC can get students from various areas outside the camp, namely from other refugee camps, IDP camps and villages in the Karen state of Myanmar, Thai Karen villages and also from other ethnic groups of Thailand and Myanmar such as Mon, Kachin, Karenni or Kayah, Lahu, Lisu, Shan, among others.

The biography of the KKBBSC directors also shows that they have a close connection with Baptist institutes in other countries. Rev. Jerry Linn (1922-2004), the first principal of KKBBSC (1983-1990), graduated with a B.Th from a seminary in Insein, Myanmar. He has four sons, all of whom graduated in theology from Bangkok Bible College and one came back to work as a teacher at KKBBSC. Rev. Dr. Saw Simon (1949-2015) was the second principal of KKBBSC during 1990-2015. ${ }^{18}$ He graduated with a B.Th from Myanmar Institute of Theology (MIT, then Burma Divinity School), and an M.Th and doctoral program at the Asian Baptist Graduate Theological Seminary (ABGTS) in the Philippines in 1987. He has three daughters who became citizens of Canada after relocating there. One was continuing her master's degree study in theology at the time of the interview in 2012.

As the refugee camp can connect easily internationally via mobile and internet technology, the principals can maintain close relationships with their former schools and Karen Baptists who have relocated in other countries worldwide. This network helps to provide places for outstanding students from KKBBSC to continue their higher education in places like Nagaland and the Philippines. In addition, foreign volunteers and visitors from Dr. Simon's networks in Thailand, India, Norway, and Sweden visit the KKBBSC almost every day. Some visit for half a day, others stay for a week. Some MA students from Philippines Baptist Theology Seminary, for example, came for some weeks to practice evangelization (Ritaeng, 2014) Volunteers from a theological school in India stay for two years to help teaching and doing other work at the KKBBSC. In fact, outsiders are not allowed to stay overnight in the camp. But with good connections with the concerned authorities, KKBBSC is exempted from this rule.

${ }^{18} \mathrm{http}: / /$ www.freeburmarangers.org/2015/08/05/dr-simon/ 
Third, the KKBBSC receives support in cash and kind from many sources. One source is from individual Karen Baptists and Baptist churches in many countries that continually donate money to help refugees and the schools. KKBBSC also gets support from faith-based organizations and INGOs which support refugees in many aspects, i.e. food for students (many of whom are orphans), allowances for teachers as well as teaching and learning materials. It has also been observed that several KKBBSC graduates are employed by some INGOs because they are capable of communicating in English. They later become a link between the KKBBSC and INGOs.

The KKBBSC's ability to receive support from many sources is also the result of the sharing of images and information on their dedication and successful operations. Also when they shared a problem with Karen Baptists and friends elsewhere through social media, support would come very fast. One example is when a fire destroyed all three KKBBSC wooden buildings, including the dormitory, in April 2012. All school computers, textbooks and other teaching materials and students' belongings were destroyed in the fire. Some students and teachers were able to record the fire outbreak along with photos of students rushing to extinguish the fire with small pails. These video clips were uploaded on social media and widely shared among the Karen and their supporters. Dr. Simon, the principal, gave an interview which can be seen on Youtube ${ }^{19}$ on that day, when he led the wedding ceremony of a former student of KKBBSC at another refugee camp. Then he received phone calls from many people from as far away as Canada and Australia asking about the fire and expressing their sympathy. He himself had not seen the video yet as he was travelling in a remote area, but people from far away saw it on social media before he did.

Only a few months after the fire, KKBBSC was rebuilt. Three more permanent buildings, larger than the original ones, were constructed and a great deal of new teaching equipment, books, and clothes were sent. Dr. Simon revealed in the same interview above that the Baptist World Alliance donated 25,000 USD, and many other organizations such as the Voice of Peace, Baptist Peace Fellowship of North America, and individuals sent more donations to rebuild KKBBSC. The inauguration of new buildings took place in April 2013, one year after the fire.

${ }^{19}$ https://www.youtube.com/watch?v=-yECZK_lFh8 accessed on June 19, 2018. 


\section{Kawthoolei Karen Baptist churches with members across national boundaries}

There are many Baptist churches operating under the KKBC on the Thailand-Myanmar borderland, including 10 Baptist churches in Bae Klaw camp. Case studies of two churches, A and B, revealed that the connections between the Baptist churches inside and outside the refugee camp, including the churches in Western countries, can be clearly seen. Moreover, members of the churches are not only refugees but Karen people in the Karen state of Myanmar, in Thailand and also in Western countries where Karen people have relocated.

As for the history and development of Church A, it was established at Village A in the Karen State of Myanmar. As fighting was escalating in 1990s, the pastor moved the church to a place closer to the Thai border, across from Thasongyang District, Tak Province. Later, the church was moved across the border to a small refugee camp which was later regrouped into the Bae Klaw camp.

Church A has a total of 137 household members but only 58 household members living in Bae Klaw camp; nine household members live in Karen communities of Thailand, 14 household members live in Karen State of Myanmar, and 56 household members resettled to third countries - Australia, Canada, the USA and Norway.

Church A organizes three services every Sunday. The first morning service is organized by the Women's Group. The service is performed in the Karen language but if some of the leaders cannot speak Karen, they are welcome to use any language that they can speak. For example, some women come from Yangon and consequently cannot communicate in the Karen language fluently, so they prefer to use Burmese during the service. The Women's Group committee has its members lead services on a rotational basis, but the service is not exclusive to women. During the morning service, the leader shares Bible scriptures, sometimes singing service songs and participants are welcomed to share their testimony.

The offering during the morning service usually amounts to around 300 Thai baht, which is used for group activities such as attending group training sessions and workshops, and some money is sent to the KKBC's Women's Group.

Church A operates a Sunday school before the second service. The Sunday school leader teaches two Bible study classes, one for children and the other for youth with Bible scriptures and Christian 
songs taught at both classes. The second service begins around $10 \mathrm{am}$. and finishes around $12 \mathrm{pm}$. Children and youth share what they learned from Sunday school and sing Christian songs. The pastor preaches and the service generally includes hymns which are then followed by an offering, the average collection being around 2,500 Thai baht per week. The third service is the youth service and is arranged by the church youth committee. The youth committee nominates members to take the lead in services, who then rotate the role among themselves. This service also collects about 300 Thai baht per week which is used for youth activities such as music contests and uniforms for sports competitions as well as to support other KKBC youth organizations. The church's income comes from every member, including the members who have resettled in third countries, which has a significant impact on Church A's budget.

Church B's history is similar to that of Church A in that it was established in village B of Karen State where most members are from. Since the beginning until the present day, there have been five pastors leading the church. The first graduated from a Bible school belonging to the Karen Baptist Convention (KBC) of Myanmar. After he left the church, Pastor Number 2 succeeded him. When the heavy fighting between KNU and the Burmese army came closer to the village, some church members considered it unsafe to continue living in a war zone and consequently moved to a small refugee camp, located near a Thai-Karen village in Thasongyang District, Tak Province. Meanwhile some church members did not follow Pastor Number 2 to Thailand but remained in Village B. When the smaller camp was dissolved, the church together with the smaller camp members moved to Bae Klaw camp.

Church B has 863 members, 278 of whom live in the refugee camp, with the others still living in Village B in Karen State of Myanmar while many have resettled in other countries such as Norway, Sweden, Canada, the USA, New Zealand and Australia. The church members keep their names registered with Church B in Bae Klaw camp, even when they resettle abroad. Most of the members living abroad send financial support back to Church B every year via the church bank account.

After Pastor Number 2 passed away, Pastor Number 3 succeeded him for the following few years. This pastor graduated from the Home Mission School which is run by the Yangon Churches Association, KBC. However, eventually Pastor Number 3 moved back to the Karen State 
and started a new church. After he left, the Church B committee invited Pastor Number 4 who had been a commando chief of the KNU but later resigned to continue his study at the KKBBSC. However, he served at Church B only for a few years, then moved to resettle in the state of North Carolina, USA. He served as a pastor there and also worked for the Karen Baptist Church of USA (KBCUSA), and remained in contact with Church B in Bae Klaw camp. Then the church committee invited Pastor Number 5 to assume the vacant leadership position. Pastor Number 5 earlier came from Village B to work in Thailand as a migrant worker. But later in 2003 he moved to a refugee camp to take an advanced course at the KKBBSC and graduated in 2004, becoming Church B's pastor in 2007. However, according to Karen Baptist regulations, only a reverend can give communion and so Pastor Number 5 has invited a reverend from the KKBC to carry out the duty.

Every Sunday, the church committee and church leaders or deacons visit church members, with the women's groups also visiting women at home, and the youth studying at Sunday school. The church also arranges mission trips to Thai Karen villages located near Bae Klaw camp as well as summer camps. It has often happened that the church members who live abroad return to have wedding ceremonies at their church in the refugee camp. Some also come back to organize thanksgiving with the church's remaining members and some return merely for fellowship. Pastor Number 5 has encouraged the membership living abroad to keep their names registered with the church of their adopted country but these members often refuse because of their strong desire to keep their names registered at the same place as their ancestors.

From the above description, it can be seen that the refugee camps provides safe space for the operation of the churches. The churches operate not only similarly to other churches outside the camp, but also with the regular substantial support from members who live abroad. Both churches' members live in many places: at their original village in Myanmar, in the refugee camp, outside the camp in Thailand and in Western countries. In this way, the church boundary is not fixed, but blurred as it can extend to many places and countries. The mobile, flexible and transnational operations of the churches contribute to the expansion of the Karen Baptist churches. 


\section{DISCUSSION}

This paper has described the history and the operation of Kawthoolei Karen Baptist Bible School and College (KKBBSC) and Kawthoolei Karen Baptist churches in Bae Klaw refugee camp in the Thai-Myanmar borderland. Since 1990, when the KKBBSC moved into the refugee camp, the number of teachers and students enrolled in English and Karen theological studies has increased dramatically from four teachers and six students in 1983 to more than 30 teachers and staff and 400 students in 2014. Around 1,000 graduates have worked as missionaries and development workers in the Karen State of Myanmar, as well as in Thailand, the USA and many other countries which accommodate Karen refugees. As for the Karen Baptist churches, the number of members also increased. These members reside not only in the camp but in Thailand, Karen state of Myanmar and many western countries. Some of them maintain their membership in the churches in the refugee camp although there are also churches around in their new places. They continue to donate money for the church's operation and come back to organize important ceremonies at their church in the camp.

The expansion of Karen Baptists in the number of missionaries, churches and members, as this paper argues, is largely due to the nature of the refugee camp which can be described as a liminal and exceptional zone. The concept of liminality is taken from Turner (1969) who refers to the liminal phase of rites de passage of Arnold van Gennep (1960). The phase is also called the margin or threshold which happens at the middle, after the separation and before the aggregation takes place. This can be applied to the status of the refugees who came to the camp, as they have been denied or lost Myanmar citizenship. Having lost their old status, they are in a transitional period of gaining new status as citizens of new nations. Many characteristics of the liminal state can be applied to the refugees in the camps, such as the absence of property, silence, anonymity, and acceptance of pain and suffering, which were mostly visible at the beginning of the camp's existence.

The concept of liminality also relates to the concept of state of exception by Agamben (2005) which is a space devoid of law. The refugee camps situated in Thailand are supposed to be under Thai sovereignty but the refugees living in these camps are not Thai citizens who are subject to Thai law. They are 'refugees' and/or UN card holders who are under the protection and management of the UNHCR. The three main stakeholders in the camp - the Thai state, KNU and UNHCR 
- cannot entirely enforce their laws, but they compromise and negotiate in setting up necessary guidelines/instructions to be applied for the refugees to live their life in the camp as normally as possible.

The refugee camps on the Thailand-Myanmar border have existed for more than three decades. The concept of state of exception and liminality are limited in explaining the situation in the camps for three reasons. First, there have been rules and regulations issued by different parties as a result of negotiation which can be contradictory. This opens gaps for refugees to have a way out from being confined under one system. Second, organizations such as KKBBSC and individual refugees have more connection with worldwide Karen and non-Karen Baptist, other Christian and non-Christian organizations and Karen communities and individuals who are now citizens of many western countries. The relocation of Karen refugees to third countries does not put an end to the links between them and their fellows in the camp. Some maintain membership in churches in the camp and regularly send donations to the churches. This continuity is facilitated by the good roads passing by the camps, electricity and internet connection, and close connections with around 20 INGOs, all of which contribute to the very special nature of refugee camps in the Thailand-Myanmar borderland. All of these factors help the refugees to become a part of the world and not an isolated entity. The second reason also leads to the third reason, that the refugees are not silent with an absence of property and status, as in the liminal state, described by Turner (1969). There are varying degrees of wealth as some have higher ranks and can possess more property and have profitable businesses in the camp.

After Myanmar changed toward a more democratic system and opened relations with other countries, the issue of refugee repatriation has been discussed. Since 2013, rations and support given to the refugees have been reduced. Many INGOs stopped their operations because of reduced budgets and moved to work inside Myanmar where more funding is available. At the end of the 2010s, the future of the refugees is uncertain. The transitional period will give way to a new phase, which it is hoped, will be better for the refugees/displaced people. 


\section{REFERENCES}

Agamben, G. (2005). State of exception. (Translated by Kevin Attell). Chicago: University of Chicago Press.

Chung-Chi, C. (2012). Nationalism, Refugees and Territories: The Karen's struggle for national space. Journal of Social Sciences, Chiang Mai University. 24(1-2/2555), 117-157.

Buadaeng, K. (2008). Moei river frontier and the Karen-Khon Muang ethnic relations. In Thai. Faculty of Social Sciences, Chiang Mai University.

Gennep, A. van. (1960). The rites of passage. (Translated by Monika B. Virzedom and Gabrielle L. Caffee). Chicago: University of Chicago Press.

Gravers, M. (1996). The Karen making of a nation. Asian Forms of the Nation. Stein Tonnesson and Hans Antlov. (Eds.), Surrey: Curzon Press.

Horstmann, A.A. (2011). Sacred spaces of Karen refugees and humanitarian aid across the Thailand-Burma border. ASEAS - Austrian Journal of South-East Asian Studies, 4(2), 254-272.

Keenan, P. (2011). Discrimination, conflict and corruption: The ethnic states of Burma. S.I.: Strategic Studies Department. Ethnic Nationalities Council-Union of Burma.

Lee, S.K. (2001). The adaptation and identities of the Karen refugees: A case study of Mae La refugee camp in Northern Thailand. (M.A. Thesis (Graduate Interdisciplinary Program in Area Studies)). Seoul National University. South Korea.

Masanthia, J. (2000). The role of western non-governmental development organizations in assisting the Karen refugees along the Thai-Burma border. In Thai. (M.A. Thesis (Politics and Public Administration)). Chiang Mai University. Thailand.

Rajah, A. (1990). Ethnicity, nationalism, and the nation-state: The Karen in Burma and Thailand. Ethnic Groups across National Boundaries in Mainland Southeast Asia. Singapore: Institute of Southeast Asian Studies.

Renard, R.D. (1990). The Karen rebellion in Burma. In Premdas, R.R., S.W.R. de A. Samarasinghe, \& Anderson, A.B. (Eds.), Secessionist Movements in Comparative Perspective. London: Pinter Publishers.

Ritaeng, P. (2014). Karen bible college and experiences of the youth in refugee camp at Thailand-Burma borderland. In Thai. (M.A. Thesis (Social Development)). Chiang Mai University. Thailand.

Smith, M. (1999). Burma: insurgency and the politics of ethnicity. London: Zed Books. 
Social Development and Welfare Department. (2002). Directory of highland communities in 20 provinces of Thailand 2545 B.E. In Thai. Social Development and Welfare Department, Ministry of Social Development and Human Security.

Turner, V. (1969). The ritual process: Structure and anti-structure. New York: Aldine de Gruyter. 